Martin Haim Edelist

Uniwersytet Jagielloński

\title{
Mandelsztam w pułapce Woroneża. (Tłumacze w pułapce Mandelsztama)
}

\author{
Mandelsztam Entrapped in Voronezh. (Translators entrapped by Mandelsztam)
}

Abstract: The author presents the historical and biographical circumstances that led Osip Mandelsztam to write the poem with the incipit ***(Пусти меня, отдай меня, Воронеж...) Two translations were confronted with the Russian original, that of Stanisław Barańczak and Jarosław Marek Rymkiewicz. The main part of the essay offers a proposal of interpretation of this Mandelsztam's lyric as well as detailed discussion and evaluation of the measures adopted by the translators to make this poem available to the Polish reader.

Keywords: Russian poetry in the 20th century, Osip Mandelsztam, Voronezh, translation, Stanisław Barańczak, Jarosław Marek Rymkiewicz, translation criticism

Streszczenie: Autor artykułu przedstawia okoliczności historyczne i biograficzne, które doprowadziły do napisania przez Osipa Mandelsztama wiersza o incipicie *** (Пусти меня, отдай меня, Воронеж...) Z rosyjskim oryginałem skonfrontowane zostały dwa polskie tłumaczenia autorstwa Stanisława Barańczaka i Jarosława Marka Rymkiewicza. W głównej części szkicu zaprezentowano propozycję interpretacji liryku Mandelsztama oraz szczegółowo omówiono i poddano ocenie zabiegi, których dokonali tłumacze, by przybliżyć utwór polskiemu odbiorcy.

Słowa kluczowe: poezja rosyjska w XX wieku, Osip Mandelsztam, Woroneż, przekład, Stanisław Barańczak, Jarosław Marek Rymkiewicz, krytyka przekładu

Niniejszy artykuł jest rezultatem badań nad tekstami, w których praca tłumacza, bardziej niż to zwykle bywa, łączy się z interpretacja, wnika w tkankę tekstu i zaciera granice między oryginałem a tłumaczeniem. Zdaje się, że jedynym sposobem na uwolnienie wspaniałego wiersza Mandelsztama o incipicie *** (Пусти меня, отдай меня, Воронеж...) spod władzy tłumaczy jest zaproponowanie krytyki przekładów i opisanie zmian, które wprowadzają do utworu. Celem tego artykułu jest zatem porównanie dwóch polskich przekładów, opis ich zalet i wad, ale przede wszystkim próba pogłębionego zrozumienia wiersza i znalezienie odpowiedzi na bardzo ważne pytanie: co w tym wypadku traci polski czytelnik, który nie obcuje z rosyjskim oryginałem, i czy coś w zamian zyskuje? 
„Bywają takie epoki, które twierdzą, że nic ich nie obchodzi człowiek” ${ }^{1}$, pisał w eseju Humanizm a wspótczesność Osip Mandelsztam. 16 maja 1934 roku oskarżono go o znieważenie Józefa Stalina w utworze, który odczytał w obecności kilku przyjaciół. W wierszu przyrównywał palce Stalina do robaków, jego wąsy do karaluchów, samego zaś dyktatora nazwał mordercą. W wyniku śledztwa poeta został zesłany do Czerdynia, gdzie targnął się na swoje życie. Wówczas przeniesiono go do Woroneża i tam Mandelsztam ułożył cykl wierszy znany jako Zeszyty woroneskie 1935-1937, który Nadieżda Mandelsztam nazwała "księgą zesłania i zguby”2.

Czterowiersz z incipitem Пусти меня, отдай меня, Воронеж... jest właściwie nieprzetłumaczalny, a każda próba oddania mnogości i zawiłości rosyjskich znaczeń to walka z góry skazana na niepowodzenie. Należy zatem docenić wysiłek tłumaczy ośmielających się wejść w dialog z twórcą, którego poezja cechuje się niezwykłą kondensacją znaczeń aż do granic werbalnej ekspresji. „Tam, gdzie rzecz równa się streszczeniu, pościel jest nietknięta, tam poezja, by tak rzec, nawet nie nocowała"3, pisał Mandelsztam. Trzeba by raczej zwrócić uwagę na to, co w przekładzie staje się nieuchwytne, a następnie dokonać próby porównania oryginału i jego polskojęzycznych odpowiedników. Oddajmy zatem głos Mandelsztamowi, potem zaś jego tłumaczom - Stanisławowi Barańczakowi i Jarosławowi Markowi Rymkiewiczowi:

Пусти меня, отдай меня, Воронеж:

Уронишь ты меня иль проворонишь,

Ты выронишь меня или вернешь, -

Воронеж - блажь, Воронеж - ворон, нож.

Апрель $1935^{4}$.

A teraz Barańczak

Niech mnie wypuści, zwróci już Woroneż -

Miasto, czy mnie uronisz, czy zabronisz,

${ }^{1}$ O. Mandelsztam, Nieograbiony i nierozgromiony. Wiersze i szkice, wyb., tłum. A. Pomorski, Warszawa 2011, s. 151.

2 N. Mandelsztam, Nadzieja w beznadziei, tłum. A. Drawicz, Warszawa 1997, s. 185.

3 O. Mandelsztam, Nieograbiony i nierozgromiony..., dz. cyt., s. 283.

${ }^{4}$ Zob. http://mandelshtam.velchel.ru/index.php?cnt=5\&rhime=st_75, dostęp: 12.12.2016.

5 Wiersz Mandelsztama ma jeszcze jedną wersję przekładu zamieszczoną w drugoobiegowym wyborze O. Mandelsztam, Późne wiersze, wyb., tłum., oprac. S. Barańczak, Warszawa 1979 (publikacja w drugim obiegu - NOWA), przedrukowywaną w kolejnych wydaniach podziemnych (Enklawa 1981, Warszawa [b.w.] 1983). Wydania te są zresztą przedrukami z edycji londyńskiej „Oficyny Poetów i Malarzy” z 1977 roku, gdzie czytamy:

Wypuść mnie wreszcie, zwróć mnie już, Woroneż -

Uronisz mnie, zabronisz czy obronisz, 
Czy mnie poskromisz, czy poronisz w kurz?

Woroneż - stróż, Woroneż - wroni nóż ${ }^{6}$.

\section{i Rymkiewicz ${ }^{7}$ :}

Wypuść mnie już, oddaj mnie im, Woroneż,

Zabronisz mnie czy zwrócisz, czy zawronisz,

Czy mnie uronisz, obrócisz w perz i kurz,

Woroneż - perz, Woroneż - wrona, nóż ${ }^{8}$.

„Woroneż w roku 1934 okazał się ponurym, wygłodniałym miastem. Różne mieszkania, sąsiedzi samogoniarze i prostytutki” - wspominała $\mathrm{Na}$ dieżda Mandelsztam ${ }^{9}$ żona poety. I dodała:

woroneska pauza była ogromnym szczęściem. Osipowi (...) bardzo podobało się miasto (...); często jednak przeklinał je i chciał uciekać. Przymus pobytu dręczył go tak bardzo jak zamknięte drzwi. (...) W chwilach desperacji ogarniała go chęć ucieczki dokąd oczy poniosą, był jednak przypisany do określonego miejsca. (...) W ten sposób Osip (...) spędził w Woroneżu całe trzy lata i tylko raz przekroczył granice dozwolonego obwodu, wyjeżdżając do tambowskiego sanatorium, z którego zresztą od razu uciek $\mathfrak{1}^{10}$.

Nic dziwnego więc, że na początku pierwszego wersu pojawia się apostrofa do miasta, które de facto jest bohaterem tekstu. Zwracający się do Woroneża podmiot, który można utożsamić z poetą, nadaje miastu cechy istoty żywej. Woroneż stanowi synonim oprawców, jawi się jako miasto demoniczne. Próba nawiązania z nim kontaktu jest świadectwem zwątpienia w ludzi, gdyż w rzeczywistości podmiot zwraca się właśnie do nich, ale niejako ponad ich głowami.

Użyty $\mathrm{w}$ pierwszym wersie tryb rozkazujący (пусти) można rozumieć zarówno jako prośbę, jak i wyzwanie. Barańczak niepotrzebnie dodaje w tym miejscu partykułę „niech”, zaś Rymkiewicz modulant „już”, sugerując

Czy mnie poskromisz, czy poronisz w kurz -

Woroneż - stróż, Woroneż - wroni nóż.

Przekład, który analizuję w szkicu, był wielokrotnie przedrukowywany w wyborach wierszy Mandelsztama, począwszy od przywoływanego przeze mnie wyboru Poezji w opracowaniu Marii Leśniewskiej z 1984 roku, i jest bodaj najbardziej rozpowszechniony.

${ }^{6}$ O. Mandelsztam, Poezje, wyb., red., posł. M. Leśniewska, Kraków 1984, s. 401.

7 Przekład Rymkiewicza powstał w drugiej połowie lat sześćdziesiątych, z przeznaczeniem do wydania w wyborze Poezji Mandelsztama w opracowaniu Ryszarda Przybylskiego (1971).

${ }^{8}$ O. Mandelsztam, Trzydzieści trzy wiersze i kilka fragmentów, tłum., komentarze J.M. Rymkiewicz, Kraków 2003, s. 35.

9 N. Mandelsztam, dz. cyt., s. 125.

${ }_{10}$ Tamże, s. 139. 
tym samym, że po pewnym okresie pobytu w Woroneżu podmiot zwyczajnie pragnie to miasto opuścić. Omdaŭ wyraża desperację człowieka pragnącego wyrwać się z pułapki. Tym razem Barańczak proponuje „już”, natomiast Rymkiewicz dokonuje interpretacji tekstu, dodając: „oddaj mnie im”.

Rosyjskie уронить znaczy upuścić, obalić, przewrócić, zgubić, zrzucić czy zarzucić, opuścić, uronić i wreszcie narazić na szwank ${ }^{11}$. Właściwe znaczenie czasownika użytego w wierszu sytuuje się gdzieś pomiędzy wszystkimi jego polskimi odpowiednikami. Proponując „uronisz”, Barańczak sugeruje przeoczenie podmiotu, który dla Woroneża jest mało ważny. W ten sposób tłumacz akcentuje znikomą wartość jednostki. Rymkiewicz dopisuje Mandelsztamowi czasownik „zawronisz”, który - jak mniemam - ma stanowić ekwiwalent gry ze słowem Woroneż, którą Mandelsztam czyni jedną z zasad organizacji tekstu.

Jeszcze trudniej przetłumaczyć czasownik проворонить - przegapić, sprzeniewierzyć. Tym razem Rymkiewicz tłumaczy go jako „zabronisz”, a Barańczak podąża jego śladem. Zdaje się, że chodzi o sprzeniewierzenie, zaprzepaszczenie niezbywalnej wartości pojedynczego człowieka przez złowrogą siłę, która kryje się pod powierzchnią słowa Woroneż.

Jeśli stwierdzić, że выронить znaczy upuścić, okaże się, że znaczenie tego czasownika pokrywa się ze znaczeniem użytego wcześniej yронить ${ }^{12}$. Rymkiewicz użył w swoim przekładzie formy „uronisz”, która w oryginale pojawiła się wcześniej. Barańczak proponuje zaś „poronisz w kurz”, co ma zapewne zaakcentować podobieństwo Woroneża i Eliotowskiej Ziemi jatowej. Podpowiedź ta jest jednak zbędna - w oryginale nie ma miejsca na dodatkowe słowa. Zaimek mbl (niekonieczny z przyczyny obecności w języku rosyjskim podmiotów konotowanych) wzmaga dramatyzm wypowiedzi i każe odbiorcy raz jeszcze wrócić do słowa klucza, do Woroneża. Jest to bowiem tajemnicze zaklęcie, wokół którego koncentrycznie układają się kolejne fragmenty tekstu. Siła tej nazwy jest tak wielka, że pozwala związać ze sobą pozornie obce sobie słowa, przechwycić je i zamknąć w obrębie jednego wiersza. Woroneż to także słowo pułapka, w którą wpadła myśl poety. Jak pisze Nadieżda Mandelsztam - „czytając w dziecinnych latach o rewolucji francuskiej, często zadawałam sobie pytanie, czy można ocaleć w czasie terroru. Obecnie wiem już na pewno, że nie. Ten, kto oddychał powietrzem terroru, jest zgubiony, nawet jeśli przypadkiem pozostał przy życiu"13. Zeszyty woroneskie można jednak odczytać także jako afirmację poezji i siły twórczej, niezależnie od tego, że utwory w nich zawarte ukazują głównie - jak w Wierszach o nieznanym żotnierzu - los człowieka schwytanego w pułapkę epoki.

${ }^{11}$ Znaczenia rosyjskich słów podaję za Wielkim stownikiem rosyjsko-polskim z kluczem polsko-rosyjskim, red. J. Wawrzyńczyk, M. Kuratczyk i in., Warszawa 2004.

${ }_{12}$ Problem polisemii polskich przyimków został szczegółowo omówiony w książce Renaty Przybylskiej Polisemia przyimków polskich w świetle semantyki kognitywnej, Kraków 2002. W książce tej można również odnaleźć obszerną listę prac naukowych skupionych wokół zagadnienia wieloznaczności prefiksów, także tych rosyjskich.

${ }^{13}$ N. Mandelsztam, dz. cyt., s. 273. 
Różnica między выронить а уронить jest słabo wyczuwalna. Podczas gdy prefiks „y-” informuje tu o u-traceniu czegoś, przedrostek вы- kładzie, jak się zdaje, nacisk na proces wydostawania się na zewnątrz (analogicznie „wydać”, „wyjąc"). Mandelsztam buduje w ten sposób krąg semantyczny, nie poprzestaje na odrębnych znaczeniach słów. Barańczak proponuje w tym miejscu „poskromisz" (czyli nagniesz do swojej woli, uczynisz posłusznym), a Rymkiewicz wraca do swego wcześniejszego pomysłu i pisze: „obrócisz w perz i kurz”. Rosyjskie вернуть zakłada jednak, że podmiotowi dane będzie powrócić do miejsca, z którego przyszedł. Jeszcze silniej niż w poprzednim wersie brzmi teraz zaimek ты, w którym słychać tragizm człowieka bez losu (termin Imre Kertésza).

Centralnym punktem wiersza jest nazwa miasta - Woroneż. Toponim ten od wieków niepokoi historyków i lingwistów. Zgłaszano różne propozycje etymologiczne - wrona (wroni?), szukano wyjaśnienia w językach azjatyckich ${ }^{14}$ i dopiero w 2009 roku ustalono na podstawie badań komparatystycznych, że słowo Woroneż pochodzi prawdopodobnie od praindoeuropejskiego rdzenia *var oznaczającego wodę ${ }^{15}$ - symbol życia.

Mandelsztam przyglądał się wnikliwie temu słowu, starał się odgadnąć ukryte w nim sensy i rozwinąć asocjacje brzmieniowe, co upodobniło go do twórców zafascynowanych językiem pozarozumowym. Futuryści uważali jednak, że każda samogłoska wyraża określoną myśl, a pierwsza samogłoska w słowie stanowi jego semantyczną dominantę, zatem słowa zaczynające się od tej samej samogłoski wyrażają tę samą myśl. Język pozarozumowy futurystów był więc językiem wyrażającym niepojęte, lecz kłębiące się w świadomości, nieokreślone przė̇ycia. Z tym poglądem na język poetycki Mandelsztam się nie zgadzał. Uważał bowiem, że słowo jako takie jest formą, i traktował je jako złożony kompleks zjawisk - na jego poglądy wpłynęły między innymi teorie ukraińskiego neohumboldtysty Aleksandra A. Potiebni. Ważny wydaje się także stosunek Mandelsztama do języka symbolicznego - to „szyfr myśli niewypowiadalnej”" W tym sensie staje się jasne, że do treści interpretowanego wiersza nie można się zbliżyć inaczej niż tylko przez dokładne zbadanie słów, których używa poeta.

O ile futuryści chcieli preparować czystą myśl i zamiast cogito stworzyć cogitare, o tyle Mandelsztamowi chodziło raczej o trójkąt myśli, słowa i duszy ${ }^{17}$. Badając te wzajemne zależności, poznajemy w najpełniejszy możliwy sposób piekło, w którym znalazł się Mandelsztam. Można by przyjąć, że wiersz o Woroneżu jest inkantacją, rodzajem czaru, być może jest nawet niezwykłym żartem - korzystając z koncepcji psychologicznych Sigmunda Freuda, można by powiedzieć, że żarty otwierają przestrzeń wolności, którą artysta może osiągnąć między in-

14 Я.П Мулкиджсанян, О слове „Воронеж” [w:] Русский провинциальный журнал „Воронеж”, Воронеж 2000.

15 Zob. http://www.voronezh.ru/city/history.html, dostęp: 1.08.2017.

16 R. Przybylski, Wdzięczny gość Boga. Esej o poezji Osipa Mandelsztama, Paryż 1980, s. 57.

17 Tamże, s. 38-39. 
nymi za pomocą języka. W tym sensie imię jest znakiem, który nie kieruje tylko do tego, kto je nosi, ale odsłania też jego istotę. Poznanie i zrozumienie imienia daje zatem władzę nad tym, kto się pod nim ukrywa. W tym sensie interpretowany wiersz byłby więc demonstracją siły, a język, za pomocą którego podmiot rzuca miastu wyzwanie, musiałby zostać sam w sobie uznany za dzianie się, za akcję.

Przyglądając się nazwie Woroneż, poeta wymienił kilka zbliżonych brzmieniowo słów (paronomazja), tworząc niezwykłe połączenie rytmu i znaczenia. Rozumiejąc tę taktykę, Barańczak postanowił zastąpić rosyjskie блажь (kaprys) słowem „stróż”, czym zmienił znaczenie tekstu. Kaprys, którego ofiarą pada podmiot, podkreśla kruchość i ulotność jednostki. Być może sam Woroneż jest kaprysem - uosabia tu przecież Belzebuba - Stalina, którego Mandelsztam nazywał „dziobatym diabłem” ${ }^{18}$. Za sprawą rzeczownika блажь w tekście ujawnia się przestrzeń absurdu, która niejako ex definitione jest przerażająca, gdyż wytrąca z ręki broń - cogito. To, że Woroneż jest więzieniem, Mandelsztam wielokrotnie w wierszu zaznaczył, zatem wybór Barańczaka nie wydaje się szczególnie trafny, ograbia bowiem tekst z niezwykłego wymiaru, który przywodzi na myśl sztuki Eugène’a Ionesco, Samuela Becketta i Harolda Pintera - z poczucia grozy spowodowanej utratą kontroli. Choć również Rymkiewicz dba o warstwę brzmieniową, proponując kolejny raz „perz”, rozmywa subtelne znaczenia ukryte w wierszu i tak oto jego przekład oddala się coraz bardziej od oryginału w stronę poetyckiego idiomu samego Rymkiewicza.

Dla zachowania niezwykłej symetrii Mandelsztam ponownie przywołał w końcu wiersza zaklęcie - Woroneż. Ворон to kruk, nie zaś - jak chcą, znów poświęcając znaczenie tekstu dla warstwy brzmieniowej, obaj tłumacze - wrona. Kruk jest uważany za ptaka nocy i zwiastuna śmierci; w symbolice chrześcijańskiej to także emblemat samotności ${ }^{19}$. Z kolei чёрный ворон ${ }^{20}$ to jednak przede wszystkim nazwa radzieckiej karetki więziennej, która służyła do przewożenia aresztowanych. Uwięziony w klaustrofobicznej przestrzeni Woroneża podmiot przeczuwa, że nie ma dla niego ratunku - podróż w głąb siebie jest podróżą skazańca. Ostatecznym potwierdzeniem tego przypuszczenia zdaje się zamykające tekst z niezwykłą siłą słowo нож. Ciekawie tłumaczy zakończenie Barańczak - łącząc dwa rosyjskie rzeczowniki w związek zgody z rzeczownikiem odprzymiotnikowym (,wroni nóż”), potęguje wrażenie niezwykłości, czym usiłuje - jak się zdaje - zrekompensować niedostatki w tłumaczeniu wcześniejszego блажь. Rymkiewicz pozostaje wierny tekstowi rosyjskiemu i pozostawia słowa rozdzielone przecinkiem.

Warto przyjrzeć się jeszcze wspomnianej już misternej, eufonicznej organizacji brzmieniowej tekstu. Stale powtarzają się głoski $6, p, H$, ж, spółgłoskowa osnowa ideofonu Woroneż. Ta nazwa jest zresztą wyrazem podstawowym, dominantą, która wyziera spod innych słów, tworząc centrum, wokół którego

18 O. Mandelsztam, Podróż do Armenii, tłum. R. Przybylski, Warszawa 2004, s. 18.

19 J.E. Cirlot, Stownik symboli, tłum. I. Kania, Kraków 2012, s. 168.

20 Inne określenie to чёрная Маруся, używa go Anna Achmatowa w poemacie Requiem. 
można gromadzić na zasadzie asocjacji dźwiękowej wyrazy pozornie niemające nic wspólnego z tematem. Podzielenie nazwy miasta skutkuje jednak dwoma kolejnymi niejasnymi znaczeniami. Tożsamość Woroneża okazuje się tym samym niejasna, a wyłonione słowa potęgują jedynie wrażenie echa.

Połączenia akustyczne dają także znaczenia metaforyczne ${ }^{21}$. Nieodłącznie wiąże się z tym aliteracja - Воронеж, выронишь, вернешь, ворон - służąca podkreśleniu jednej tonacji w utworze. Choć polskim tłumaczom udało się zachować jedynie związek brzmieniowy między nazwą Woroneż i wroną, homofoniczność tekstu została przez nich uchwycona w repetycjach dźwięków: w, r, ż, sz. W warstwie brzmieniowej uwagę zwraca również przyporządkowanie samogłosek przednich bohaterowi, tylnych zaś miastu. Analizując utwór w ten sposób, można zauważyć, jak niewiele słów wiąże się z podmiotem, a jak wiele z Woroneżem. Warto zwrócić uwagę na piętnastokrotne pojawienie się litery „o” (można by ją rozumieć jako synonim pustki) oraz na miękkie znaki, które - dlatego że słabiej słyszalne i niewystępujące nigdy samodzielnie - mogą symbolizować ukrytą $\mathrm{w}$ tekście nadzieję. W wierszu dominują samogłoski: $и$, o, e - gdyby pozostawić jedynie szkielet samogłoskowy słów, usłyszelibyśmy zawodzący jęk. W wypadku języków ubogich w samogłoski to zwyczajna kolej rzeczy, z drugiej jednak strony należy spojrzeć na ten niezwykły dźwięk z perspektywy wykorzystanych w tekście anagramów.

Słabością polskich tłumaczeń jest niemożliwy do oddania rosyjski ruchomy akcent, dzięki któremu początkowe rozkazy brzmią w oryginale znaczniej mocniej. W kluczowym słowie akcent pada na środku (Воро́неж), wydaje się to dawać niezwykły efekt przedłużenia dźwięku „o”. Dzięki temu udało się niemalże unaocznić rozciągnięty do granic możliwości czas i niepewność oczekiwania. Można w tym „o”, jak się zdaje, usłyszeć również niepoznawalną i groźną przestrzeń Woroneża, który jawi się jako, by użyć określenia bliskiego poezji Emily Dickinson, miasto pojemnik, w którym zawiera się podmiot. Architektura oznaczała zresztą dla akmeistów taki rodzaj sztuki, na której powinna wzorować się poezja. W twórczości Mandelsztama można znaleźć wiersz o Notre Dame, z którego wynika, że poeta pojmował gotycką architekturę jako odzwierciedlenie równowagi świata. W interpretowanym wierszu aktywna, żyjąca niejako architektura, czyli Woroneż, wskazuje jednak na coś zgoła odwrotnego - na całkowity brak niezbędnej do życia równowagi.

Niezwykłą instrumentację tego tekstu można by określić za Andrzejem Hejmejem muzycznością pierwszego stopnia. Są to „wszelkie przejawy odnoszone do sfery instrumentacji dźwiękowej i prozodii, świadomie kształtowane zarówno w związku z muzyką natury, jak i w mniejszym stopniu z muzyką kultury"22. Wyznaczniki muzyczności stanowią w interpretowanym utworze repetycje słów i całych fraz, aliteracje, paraleliczne i refreniczne struktury wierszowe, echo, eufoniczne ułożenie głosek i w końcu użycie wyrazistych brzmieniowo słów roz-

21 A. Kulawik, Poetyka. Wstęp do teorii dzieta literackiego, Kraków 1997, s. 58.

22 A. Hejmej, Muzyczność dzieta literackiego, Toruń 2012, s. 52. 
wijających jeden dźwiękowy temat. Multiplikacja bliskich fonicznie cząsteczek doprowadza do uczucia przytłoczenia powracającym brzmieniem i szybkim rytmem tekstu, co ostatecznie upodabnia wiersz o Woroneżu do labiryntu i potęguje u odbiorcy odczucie zagubienia i niemożności ucieczki. Można odnieść wrażenie, że liczba wersów mniej więcej odpowiada znikomej przestrzeni życiowej podmiotu. W tym rozumieniu warstwa brzmieniowa wiersza narzuca interpretatorowi swoje własne tempo, które powinno zostać oddane w tłumaczeniu.

Ostatecznie, nie wolno bagatelizować zapisanej pod tekstem daty - jest to integralna część utworu, która wiersz zamienia w dokument. W kwietniu 1937 roku Mandelsztam pisał w liście do Czukowskiego: „Jestem cieniem. Nie ma mnie"23. Czytamy zatem utwór będący głosem z podziemia - to piekło życia i życie w piekle. Czas historyczny wygnańców, czas cierpienia i walki z nowożytnym barbarzyństwem został przekuty w wiersz ${ }^{24}$, który może się mierzyć pod względem artystycznej doskonałości z najbardziej wstrząsającymi tekstami Imre Kertésza, Herty Müller, Tadeusza Borowskiego czy Gustawa Herlinga-Grudzińskiego. W słynnym eseju o François Villonie Mandelsztam zauważył, że poezja w XV wieku zajmowała tak doniosłe miejsce w kulturze, że przypominała państwo w państwie ${ }^{25}$. W XX wieku sytuacja zdaje się powtarzać, ale tym razem nie jest to jedynie przywilej, a raczej warunek konieczny do egzystencji poety.

\section{Podsumowanie}

Tłumaczony tekst można by porównać do zaparowanej szyby, przez którą widać - raz lepiej, raz gorzej - to, co jest za nią, oryginał. Zadaniem tłumacza jest zatem dokonać wyboru i przekazać tekst, który nawet w obcym języku pozostanie związany ze swoim twórcą. Jeśli język, na który dokonuje się przekładu, nie dysponuje określoną formą, tłumacz musi tę formę wynaleźć. Zadaniem komentatora przekładu jest opatrzeć translat komentarzem, który z jednej strony uwidoczniłby trudności, które napotyka tłumacz, z drugiej zaś strony ujawniłby słabe strony jego pracy. Jest to zadanie trudne, polegające na budowaniu mostu między oryginałem i tłumaczeniem, wygładzaniem fałd na materiale przekładu. Jednak to mimo wszystko zadanie łatwiejsze od pracy tłumacza, ponieważ nie żąda jednego i nieodwołalnego rozwiązania.

Zamierzeniem niniejszego szkicu nie była krytyka przekładów, które zaproponowali Barańczak i Rymkiewicz. Jako poeci wybrali oni ekwiwalenty korespondujące $\mathrm{z}$ wypracowanym przez siebie oryginalnym stylem oraz wrażliwością artystyczną. Nie bez znaczenia pozostają także koncepcje przekładowe obu twórców. Szkic ma raczej na celu opatrzenie tych tłumaczeń przypisami,

23 O. Mandelsztam, Nieograbiony i nierozgromiony, dz. cyt., s. 489.

${ }^{24}$ R. Przybylski, dz. cyt., s. 160.

25 Por. O. Mandelshtam, Selected Essays, trans. M. Sidney, Texas 1997. 
które, przez wzgląd na rozmiar i formę wiersza, nie mogą się pojawić w wydaniu przeznaczonym dla zwykłego odbiorcy, i które, przez wzgląd na wyjątkowość utworu, powinny i muszą być uwzględniane w trakcie lektury przekładu, tak by tę lekturę uczynić pełniejszą i bliższą duchowi oryginału.

\section{Bibliografia}

Bachtin M., Estetyka twórczości stownej, tłum. D. Ulicka, Warszawa 1986.

Barańczak S., Ocalone w ttumaczeniu. Szkice o warsztacie ttumacza poezji z dodatkiem Matej antologii przektadów-problemów, Kraków 2004.

Cirlot J.E., Stownik symboli, tłum. I. Kania, Kraków 2012.

Hejmej A., Muzyczność dzieta literackiego, Toruń 2012.

Historia miasta Woroneż, http://www.voronezh.ru/city/history.html, dostęp: 1.08.2017. Kwiatkowski J., Klucze do wyobraźni. Szkice o poetach wspótczesnych, Warszawa 1964. Mandelshtam O., Selected Essays, trans. M. Sidney, Texas 1997.

Mandelsztam O., Nadzieja w beznadziei, tłum. A. Drawicz, Warszawa 1997.

Mandelsztam O., Nieograbiony i nierozgromiony. Wiersze i szkice, wyd., tłum. A. Pomorski, „Warszawa 2011.

Mandelsztam O., Podróż do Armenii, tłum. R. Przybylski, Warszawa 2004.

Mandelsztam O., Poezje, wybór, red., posł. M. Leśniewska, Kraków 1984.

Mandelsztam О., Пусти меня, отдай меня, Воронеж, http://mandelshtam. velchel.ru/index.php?cnt=5\&rhime=st_75, dostęp: 12.12.2016.

Mandelsztam O., Trzydzieści trzy wiersze i kilka fragmentów, tłum., komentarze J.M. Rymkiewicz, Kraków 2003.

Мулкиджанян Я.П., О слове „Воронеж” [w:] Русский провинциальный журнал „Воронеж”, Воронеж 2000.

Przybylska R., Polisemia przyimków polskich w świetle semantyki kognitywnej, Kraków 2002.

Przybylski R., Wdzięczny gość Boga. Esej o poezji Osipa Mandelsztama, Paryż 1980.

Śniecikowska B., „Nowa muzycznośc'? Fonostylistyka awangardowa i jej wspótczesne kontynuacje, „Acta Universitatis Lodziensis. Folia Litteraria Polonica” 2012, nr 1.

Wielki stownik rosyjsko-polski z kluczem polsko-rosyjskim, red. M. Kuratczyk, J. Wawrzyńczyk i in., Warszawa 2004. 